\title{
Financial Reporting Opacity, Audit Quality and Crash Risk: Evidence from Japan
}

\author{
Soo-Joon CHAE $^{1}$, Makoto NAKANO ${ }^{2}$, Ryosuke FUJITANI ${ }^{3}$
}

Received: October 01, 2019 Revised: November 01, 2019 Accepted: November 15, 2019

\begin{abstract}
This study examines the effect of financial reporting opacity and audit quality on stock price crash risk using listed firms in Japan. This study is the first research to examine the effect of financial reporting opacity on crash risk using a Japanese listed company. Furthermore, the effect of audit quality on crash risk is verified. High level auditors can mitigate crash risk by playing a role as a corporate governance device mechanism to reduce agency costs. We use a logistic regression and linear regression model to test whether financial reporting opacity and audit quality affect crash risk using listed firms in the Japanese stock exchange market during the fiscal years 2015 January through 2017 February. The results of this study suggest that the financial reporting opacity variable shows a positive relationship with CRASH, which states that a firm with more opaque financial reporting increases crash risk. The results suggest also that the firms audited by Big4 auditors experience less crash risk, implying that the audit quality in Japan can be one of the factors mitigating firm's crash risk. This study provides implications for financial reporting and audit quality to external stakeholders who wants to avoid losses.
\end{abstract}

Keywords : Financial Reporting Opacity, Audit Quality, Crash Risk, Japanese Listed Firm, Capital Market

JEL Classification Code : D52, G30, M41

\section{Introduction}

This study examines the effects of financial reporting opacity and audit quality on stock price crash risk (hereafter, crash risk) using Japanese listed firms. Crash risk is defined here as the risk of the stock price rapidly falling to a very low price to earnings ratio. Hutton, Marcus, and Tehranian (2009) interpret crash risk to be the same as tail risk, which is derived from a normal distribution as used in statistics. Investors are more receptive to risks associated with stock price falls rather than rises. Therefore, the stock price

1 First Author and Corresponding Author, Associate Professor, Division of Business Administration and Accounting, Kangwon National University, Korea. [Postal Address: Business

Administration Bld. Rm. 408, 1 KangwonDaehak-gil, Chuncheon, Gangwon-do, 23431, Korea] Email: sjchae@kangwon.ac.kr

2 Professor, Graduate School of Business Administration, Hitotsubashi University, Japan.

Email: makoto.nakano@r.hit-u.ac.jp

3 Ph.D. Student, Graduate School of Commerce and Management, Hitotsubashi University, Japan. Email: cd171002@g.hit-u.ac.jp

(c) Copyright: Korean Distribution Science Association (KODISA)

This is an Open Access article distributed under the terms of the Creative Commons Attribution Non-Commercial License (http://Creativecommons.org/licenses/by-nc/4.0/) which permits unrestricted noncommercial use, distribution, and reproduction in any medium, provided the original work is properly cited. response due to the disclosure of negative information is asymmetric (Kothari, Shu, \& Wysocki, 2009). In the traditional capital asset pricing model (CAPM), because the price earnings ratio is assumed to follow a normal distribution, the risk is distributed through diversification. In reality, however, when stock prices crash, the price earnings ratio becomes negatively skewed, which makes it difficult for investors to resolve associated risks through diversification (Ibragimov \& Walden, 2007). That is, a stock price crash, as a kind of tail risk, is unpredictable and unlikely to occur in financial and economic markets. However, once it does occur, it results in a very low price to earnings ratio. Thus, it has a significant effect on portfolio theory and asset and option pricing models (Kim \& Zhang, 2015). Huang, Liu, Rhee, and $\mathrm{Wu}$ (2012) reported that even if only $1 \%$ of the stocks listed on the US stock market (NYSE, AMEX, NASDAQ) from 1963 to 2009 were removed, the average daily price earnings ratio would be more than double. This indicates that crash risk is a serious consideration for both investors and firms.

After the stock market crash during the 2008 financial crisis, many studies focused on analyzing the determinants of the crash risk. Previous studies on crash risk examined the determinants of stock market crashes or explained the 
crash risk of individual stocks in terms of asset pricing theory. Recently, however, in addition to these factors, many studies have been conducted on the effects of corporate characteristics, including agency cost, and in particular, corporate transparency and corporate governance on stock price synchronicity and stock price crash risk (Morck, Yeung, \& Yu, 2000; Jin \& Myers, 2006; Hutton et al., 2009). From the perspective of an agency cost theory, managers have many incentives and reasons to conceal the company's negative information, including maximizing compensation contracts and escaping litigation concerns (Kothari et al., 2009). When such negative information accumulates for a long time and is not reflected in the stock price, the stock price becomes excessively higher than the actual value of the company and forms a bubble. However, when the accumulation of negative information exceeds the threshold, the information spreads to the market immediately, leading to a popping bubble, after which a crash risk appears (Jin \& Myers, 2006).

According to Jensen and Meckling (1976), a controlling shareholder is likely to act opportunistically with the aim of pursuing his own private interests in an information asymmetric environment due to high agency costs. Therefore, firms with less information asymmetry expose the lower crash risk. A variety of studies have investigated the determinants of crash risk and have reported that financial reporting opacity and corporate governance, which influence agency costs, affect the crash risk. Hutton et al. (2009) find a negative relation between information opacity and the probability of a crash risk. $\mathrm{Kim}, \mathrm{Li}$, and $\mathrm{Li}$ (2014) showed that companies with better CSR scores are less likely to experience a crash risk. They report that if the internal monitoring of the board of directors or the external monitoring of institutional investors is weak, CSR's role is particularly important in reducing crash risk. An and Zhang (2013) found that dedicated institutional investors reduce the crash risk and stock price synchronicity by mitigating managerial bad news hoarding.

Robin and Zhang (2015) report that information intermediary and corporate governance roles of auditor industry specialization reduce crash risk. Previous literature on auditors has discussed the advantages of highly skilled auditors. Particularly, researchers have verified the effect of audit quality on the quality and profit adjustment of accounting reporting (Becker, Defond, Mark, Jiambalvo, \& Sunramanyam, 1998; Myers, Myers, \& Omer, 2003). Therefore, by monitoring the adequacy of corporate information and whether it is being reported in line with accounting standards as well as by determining whether there is concealed accounting information to reduce agency cost, it is possible to reduce crash risk.

In other words, as the opacity of financial reporting increases, the crash risk increases, thus, good corporate governance reduces crash risk. This study analyzes whether financial reporting opacity predicts crash risk in Japanese listed firms. According to Hutton et al. (2009), the prior three-year moving sum of the absolute value of discretionary accruals is used as a proxy for the firm's financial reporting opacity. Furthermore, we examine the effect of audit quality on crash risk using the Big4 accounting firm, which is a proxy for audit quality, as an indicator of good corporate governance.

This study measures crash risk in three ways. First, we use a crash risk dummy variable (CRASH) to indicate whether a firm experiences a weekly stock return of less than $0.1 \%$ in the standard normal distribution of firmspecific weekly stock returns (Jin \& Myers, 2006, Hutton et al., 2009). In addition, Chen, Hong, and Stein (2001) suggested two measures of crash risk by analyzing the factors by which individual stock returns had a negative skewness.

In this study, we use a negative conditional skewness of a firm-specific weekly return (NSKEW). Up-to-down volatility of firm-specific weekly returns (DUVOL) were used as a measure for crash risk. We use data of Japanese non-financial listed firms between the fiscal years of January 2015 to February 2017. We find that firms with more opaque financial reporting experience more crash risk. This result is consistent with the hypothesis that information asymmetry by earnings management behaviors allows managers to conceal negative information and accumulate in the company, leading to a future crash risk. Additionally, better audit quality negatively relates to the probability of crash risk. This result supports the hypothesis of this study that companies with high level audit quality, in the sense of a Big4 audit, mitigates crash risk by reducing information asymmetry. These results were all robust in the three measures of crash risk.

As Japan's stock market boasts the world's second-largest market capitalization after the United States ( $\$ 6.17$ trillion based on the closing price on August 3, 2018), studies on stock price crashes in the Japanese capital market make significant contributions to our understanding of how to avoid such crashes in the future. This study is organized as follows. The next section reviews the prior literature. In Section 3, we describe the measurement, sample selection, and test model. Section 4 represents the descriptive statistics, correlation coefficient matrix, and the results of the main analyses. Section 5 concludes this study.

\section{Literature Review and Hypothesis Development}

In the market, crash risk can be defined in various ways. However, one characteristic of crash risk is negative skewness, which eventually leads to greater volatility in negative returns. Prior studies have been conducted to explain this asymmetric distribution or asymmetric volatility. Traditional financial theories report changes in operating and financial leverage models under the assumption of a representative investor, volatility feedback mechanisms, and stochastic bubble as determinants of crash risk. However, 
recent studies have developed methods related to crash risk with the characteristics of individual companies.

The determinants of firm-level crash risk are extensive, but the most important factor suggested by previous studies is the agency cost that causes information asymmetry. (Hutton et al., 2009; Kim \& Zhang, 2015). If information asymmetry between managers and investors is high, negative news from the company is not delivered to the capital market in a timely manner. Managers with information advantages are likely to manipulate, delay, and conceal the information to maximize their own private benefit (Healy \& Palepu, 2001; Jin \& Myers, 2006). However, even if managers continually attempt to hoard the disclosure of negative information, they cannot accumulate negative information beyond some critical point. When the accumulation of negative information passes the threshold, it spreads quickly into the market, resulting in a crash in the stock price (Jin \& Myers, 2006). Hutton et al. (2009) studied the relationship between corporate accounting opaqueness, crash risk and negative skewness by using the three-year moving-sum of absolute value of discretionary accruals as a proxy for financial report opacity. They report that firms with more opaque financial statements are more prone to crash risk.

Kim and Zhang (2015) demonstrate that conditional conservatism reduces a firm's crash risk. Kim, Wang, and Zhang (2016) report that financial reporting with an increase in comparability reduces the crash risk. Ertugrul, Lei, Qiu, and Wan (2017) found that firms with larger 10-K file sizes and a higher proportion of uncertain and weak expressions have a greater future crash risk. They stated that this result supports the argument that the readability and tone ambiguity of a firm's financial disclosures are related to managerial information hoarding.

In summary, previous studies report that crash risks can be reduced when financial reporting effectively plays a role of reducing agency costs between external and internal stakeholders. This study examines the effect of corporate financial reporting opacity on crash risk in Japanese listed firms following Hutton et al. (2009). The prior 3-year moving sums of the absolute value of discretionary accruals are used to measure financial reporting opacity (Hutton et al., 2009). Discretionary accruals have been used as a measure of earnings management in many previous studies. Earnings management generally refers to the intentional involvement of managers in the financial reporting process for the purpose of private interests. Managers adjust their performance by overusing accrual discretion or actually changing management decisions. Therefore, in this study, the accumulation of earnings management is regarded as the opacity of financial reporting since earnings management behavior can be used as a mechanism to hide particularly bad news. Financial reporting opacity is expected to increase crash risk. Accordingly, the first hypothesis is formulated as follows:

Hypothesis 1: Firms with more financial reporting opacity experience more crash risk.
There is empirical evidence that better corporate governance which is designed to reduce agency cost also mitigates future crash risk. An and Zhang (2013) report that the supervision of dedicated institutional investors prevents unfavorable disclosures from managers and mitigates crash risk. Callen and Fang (2013) empirically analyzed whether institutional investors can monitor the management of a company and reduce the crash risk. As a result, they suggest that institutional investors reduce the crash risk by monitoring managers' opportunistic behavior. Robin and Zhang (2015), using Chinese firms, found that the audit industry specialization measured as effective corporate governance reduces crash risk. Aman (2013) conducted a study of Japanese firms and reported that crash risk increases with media coverage. Callen and Fang (2016) show that auditor tenure increases the auditors' clientspecific knowledge and hence enhances the auditors' ability to detect and deter bad news hoarding by clients, thus reducing crash risk. These previous studies show that companies with good corporate governance are less likely to face the risk of a crash.

From this perspective, this study seeks to consider the role of the auditor as an effective form of corporate governance. If the auditor plays its role as a corporate governance, it will reduce crash risk by reducing agency costs. Specifically, this study considers Big4 auditors as a proxy for audit quality measure. Previous studies have found that the impact of damage to reputation increases with the size of the accounting firm; therefore, the quality of the audit increases, and thus significantly inhibits the discretionary power of the audited firm (DeAngelo, 1981; Francis, Maydew, \& Sparks, 1999; Palmrose, 1989). These studies indicate that firms audited by highly skilled auditors see reduced selective disclosure by managers and, therefore, face smaller stock price crashes. Second, through efficient techniques and expertise, highly skilled auditors can improve the quality of financial statements by getting managers to disclose negative information in a timely manner. Therefore, if a better auditor acts as an effective corporate governance mechanism to reduce agency costs between internal and external stakeholders, high-quality auditors will reduce the crash risk. Accordingly, we expect the second hypothesis as follows:

Hypothesis 2: Firms with higher audit quality experience less crash risk.

\section{Research Methodology}

\subsection{Variable Measurement}

\subsubsection{Crash Risk}

Previous studies define crash risk in the context of the negative skewness of price earnings ratio distribution (Callen \& Fang, 2015; Chen et al., 2001; Hutton et al., 2009; 
Kim et al., 2014). Chen et al. (2001) use the negative skewness of the price earnings ratio as a proxy for crash risk. Hutton et al. (2009) measure crash risk by the mean price earnings ratio standard deviation multiplied by 3.09 , that is, the stock price fluctuation belonging to the lower $0.1 \%$ of the price earnings ratio distribution.

To measure crash risk, we first estimate firm-specific weekly returns, from which the influence of the market is removed. Specifically, in accordance with the market model of Chen et al. (2001), the following regression, Equation (1), uses the weekly returns $r_{j t+1}$ of individual firm stock $\mathrm{j}$ at time $\mathrm{t}$ as the dependent variable, and the value weighted market index $r_{m t}$ at the previous period and at the following period as the independent variable. The value weighted market index is included in the previous and following periods to control for non-synchronous trading and estimate firmspecific weekly returns (Dimson, 1979).

$$
\begin{aligned}
\gamma_{j, t}=\alpha_{0} & +\alpha_{1} \gamma_{m, t-2}+\alpha_{2} \gamma_{m, t-1}+\alpha_{3} \gamma_{m, t}+\alpha_{4} \gamma_{m, t+1} \\
& +\alpha_{5} \gamma_{m, t+2}+\epsilon_{i, t}
\end{aligned}
$$

The residual estimated from Equation (1) $\varepsilon_{i, t}$ has a very skewed distribution. Thus, to form a symmetric distribution roughly, we add 1 to the residual term $\varepsilon_{i, t}$ and then we define the natural logarithmic value $W_{j, t}$ as the firm-specific weekly returns shown in Equation (2) as follows (Hutton et al., 2009; Kim et al., 2011).

$$
W_{j, t}=\ln \left(1+e_{j, t}\right)
$$

In this study, three crash risks were measured by using firm-specific weekly returns $W_{j, t}$ estimated Equation (2).

The first crash risk variable, CRASH, is a dummy variable taking one if the firm experiences crash risk, but is zero otherwise. Specifically, if the firm-specific weekly return in year $\mathrm{t}$ is smaller than the negative value obtained by multiplying 3.09 by the standard deviation of the mean value of firm-specific weekly return distribution over the overall period, then the firm is considered to have experienced a stock price crash. Therefore, the CRASH variable is a dummy variable that has a value of 1 if a firm experiences one or more firm-specific weekly returns falling at least 3.09 standard deviations below its mean value in a given year, and zero otherwise. The cut-off of a 3.09 standard deviation was chosen because the frequency of the lower $0.1 \%$ of the overall mean weekly return distribution is extremely low (Hutton, Marcus, \& Tehranian, 2009; Kim et al., 2011).

The second crash risk measure, the NCSKEW variable, is a continuous variable that depicts the magnitude of crash risk. If the crash risk of a particular firm is high, the firmspecific weekly return will be left-skewed. Therefore, if the skewness of the firm-specific weekly return is severe, the crash risk is considered high. Therefore, the NSKEW variable was defined as the firm's negative skewness, and was measured using the following Equation, according to Chen et al. (2001).

$$
N S K E W=-\left[n(n-1)^{\frac{3}{2}} \sum W^{3}{ }_{j, t}\right] /\left[(n-1)(n-2)\left\{\sum W^{2}{ }_{j, t}\right\}^{\frac{3}{2}}\right]
$$

The variable $n$ is the number of observations in the firmspecific weekly return in year $\mathrm{t}$, and $\mathrm{W}$ is the firm-specific weekly return estimated in Equation (2). For the convenience of interpretation, a negative value was taken for $N S K E W$ in consideration of the interpretation that the higher the negative skewness value, the higher the crash risk.

The third crash risk measure, the $D U V O L$ variable, was measured as asymmetrical volatility between positive and negative stock returns. In order to measure the DUVOL variable, the individual weekly returns of individual stock $j$ have weekly samples ("down" weeks) lower than the annual average stock returns ("down" weeks) and weekly samples higher than the annual average stock returns ("up"). weeks). The third crash risk measure was obtained by dividing the standard deviation of the sample group with the firmspecific weekly return below the annual average stock return by the standard deviation of the sample group with the firmspecific weekly return higher than the annual average stock return.

$$
\text { DUVOL }=\log \left\{\left(n_{u}-1\right) \sum_{\text {Down }} W_{j, t}^{2} /\left(n_{d}-1\right) \sum_{U p} W_{j, t}^{2}\right\}
$$

\subsubsection{Financial Reporting Opacity}

The independent variable of the first hypothesis of this study is financial reporting opacity. The prior 3-years moving sum of the absolute value of discretionary accruals is used to measure financial reporting opacity (Hutton et al., 2009). And we adopted Kothari et al.'s (2005) performancematched model to estimate discretionary accruals following Equation (3)

$$
\begin{aligned}
T A_{i, t} / A_{i, t-1}= & \beta_{0}+\beta_{1}\left(1 / A_{i, t-1}\right)+\beta_{2}\left[\left(\Delta S_{i, t}-\Delta A R_{i, t}\right) / A_{i, t-1}\right] \\
& +\beta_{3} P P E_{i, t} / A_{i, t-1}+\beta_{4} R O A_{i, t}+\varepsilon_{i, t} \\
T A i, t \quad= & \text { Net income }- \text { cash flow from operating } \\
& \text { activities; } \\
\text { Ai,t-1 }= & \text { Total assets; } \\
\Delta S i, t= & \text { Changes in sales; } \\
\Delta A R i, t= & \text { Changes in accounts receivable; } \\
\text { PPEi,t }= & \text { Tangible assets }- \text { land-construction in } \\
\text { ROAi,t }= & \text { progress; } \\
\varepsilon & =\text { Residuals; } ; \text { and } \\
i, t & =\text { firm, year }
\end{aligned}
$$

To reduce measurement errors when estimating discretionary accruals, industries with fewer than 20 
industry-year samples were excluded. The prior 3-years moving sum of the absolute value of the residual of Equation (3) is taken to verify [Hypothesis 1]. A high level of absolute value of discretionary accruals signifies that the financial reporting opacity is high.

\subsubsection{Audit Quality}

Whether or not a firm was audited by a large accounting firm was used as a factor to substitute for higher audit quality. Becker et al. (1998) argue that large accounting firms are more likely to reduce managerial adjustments to earnings than other accounting firms. Jensen and Meckling (1976) also note that large accounting firms have relatively high independence due to their low economic dependence on the audited firm; they also significantly lower the audited firm's probability of misconduct. Previous studies defined audit quality as high or low depending on the presence of an alliance with the Big 4 accounting firms (Deloitte, Ernst \& Young (EY), KPMG, and PricewaterhouseCoopers ( $\mathrm{PwC})$ ). The Big 4 accounting firms were defined as substitutes for superior audit quality because previous studies have reported that they provide high-quality audits through a variety of internal training programs and peer reviews, and likely to maintain their professional brand name above other accounting firms (Becker et al. 1998, Krishnan 2003). Accordingly, we verify [Hypothesis 2] using the BIG4 dummy variable.

\subsection{Hypothesis Test Model}

This study examines whether financial reporting opacity significantly increases the crash risk. Conversely, we also examine whether better audit quality reduces the crash risk. Therefore, CRASH, NSKEW, DUVOL indicating the crash risk were used as dependent variables. The financial reporting opacity $(F R O)$ variable and Big 4 accounting firm (BIG4) variable along with the control variable were included in the independent variables to form the regression model of Equations (4) (6). As variable $C R A S H$ is a dummy variable, Equation (4) is based on a logistic regression, whereas Equations (5) and (6) are linear regression models.

$$
\begin{aligned}
\text { CRASH }_{i, t+1}= & \gamma_{0}+\gamma_{1} \mathrm{FRO}_{i, t} \text { or } B I G 4_{i, t}+\gamma_{2} \operatorname{SIZE}_{i, t} \\
& +\gamma_{3} \operatorname{SIGMA}_{i, t}+\gamma_{4} R E T_{i, t}+\gamma_{5} M B_{i, t} \\
& +\gamma_{6} L E V_{i, t}+\gamma_{7} \operatorname{ROA}_{i, t}+\varepsilon_{i t}
\end{aligned}
$$

$$
\begin{aligned}
\text { NSKEW }_{i, t+1}= & \gamma_{0}+\gamma_{1} \text { FRO }_{i, t} \text { or }_{B I G 4_{i, t}}+\gamma_{2} \operatorname{SIZE}_{i, t} \\
& +\gamma_{3} \operatorname{SIGMA}_{i, t}+\gamma_{4} \operatorname{RET}_{i, t}+\gamma_{5} M B_{i, t} \\
& +\gamma_{6} L E V_{i, t}+\gamma_{7} \operatorname{ROA}_{i, t}+\varepsilon_{i t}
\end{aligned}
$$

$$
\begin{aligned}
& D_{U V O L_{i, t+1}}=\gamma_{0}+\gamma_{1} F R O_{i, t} \text { or BIG4 }{ }_{i, t}+\gamma_{2} \operatorname{SIZE}_{i, t} \\
& +\gamma_{3} S_{I G M A_{i, t}}+\gamma_{4} R E T_{i, t}+\gamma_{5} M B_{i, t} \\
& +\gamma_{6} L E V_{i, t}+\gamma_{7} R O A_{i, t}+\varepsilon_{i t}
\end{aligned}
$$

The variables of interest in this study are $F R O$ and $B I G 4$. Here, $\gamma_{1}$, the coefficient of these variables, is the regression coefficient of interest which verifies the hypothesis. Thus, if the coefficient of FRO, $\gamma_{I}$ is a statistically significant positive value, then this indicates that as financial reporting opacity increases, the size of the crash risk increases, which is consistent with [Hypothesis 1]. Incorporating $B I G 4$ as an independent variable, if the coefficient of $B I G 4 \gamma_{l}$ is a statistically significant negative value, then this indicates that as audit quality increases, the size of the audited firm's crash risk decreases, which is consistent with [Hypothesis 2].

As control variables, Chen et al. (2001) include variables that were considered to influence crash risk. First, they add the SIZE variable to the model to control the size of the firm - the natural logarithm of the market value, and the magnitude of the unconditional volatility of the overall returns $(S I G M A)$ is included as a control variable. We included the annual arithmetic mean (RET) of the firm-

\begin{tabular}{|c|c|}
\hline Variable & Definition \\
\hline CRASH & $\begin{aligned}= & \text { Dummy variable estimated through Equation (1); } 1 \text { if } \\
& \text { a firm experiences crash risk at least once during the } \\
& \text { fiscal year, and } 0 \text { if otherwise. }\end{aligned}$ \\
\hline NSKEW & $\begin{aligned}= & \text { Negative skewness of firm-specific weekly returns } \\
& \text { over the fiscal year }\end{aligned}$ \\
\hline DUVOL & $\begin{array}{l}=\text { The log of the ratio of down-week to up-week } \\
\text { standard deviation }\end{array}$ \\
\hline FRO & $\begin{array}{c}=\text { The prior 3-years moving sum of the absolute value of } \\
\text { discretionary accruals estimated through Equation (3) }\end{array}$ \\
\hline BIG4 & $\begin{array}{l}=\text { Dummy variable, } 1 \text { if a firm is audited by big } 4 \\
\text { auditors, and } 0 \text { if otherwise. }\end{array}$ \\
\hline SIZE & $=$ The logarithm of market value \\
\hline SIGMA & $=$ The standard deviation of firm-specific weekly return \\
\hline RET & $\begin{array}{l}=\text { The average firm-specific weekly return multiplied by } \\
100\end{array}$ \\
\hline$M B$ & $=$ The ratio of the book value to market value of equity \\
\hline LEV & $=$ The ratio of the total debt to total assets \\
\hline$R O A$ & $=$ The ratio of the net income to total assets \\
\hline i,t & $=$ firm, year \\
\hline
\end{tabular}
specific weekly return. We further include return on assets $(R O A)$ to control performance, as well as firm value $(M B)$ and debt ratio $(L E V)$. To verify future crash risk according to the current financial reporting opacity and audit quality, all of the independent variables are measured the previous period rather than the current period in the analytical model. Variable definitions are shown in $\langle$ Table $1>$ below.

Table 1: Variable Definition

\subsection{Sample}

Our initial sample comprises all of Japanese nonfinancial listed firms during the fiscal years 2015 January through 2017 February. Financial data and stock price data are obtained from Nikkei NEEDS Financial QUEST and audit firm data is collected from Nikkei NEEDS Corporation Basic Data. The final sample size is 3,102 firm-year observations. Following existing literature, we exclude financial firms and winsorize each variable falling in the top or bottom $1 \%$. 


\section{Research Results}

\subsection{Basic Statistics}

<Table 2> shows the year-firm descriptive statistics for the 3,102 year-firms used in this study. The mean of the crash risk dummy variable $(C R A S H)$ used as the dependent variable was 0.241 , indicating that 747 year-firms experienced crash risk during the sample period. The mean of $F R O$ is 0.053 , similar to previous research. The mean of $B I G 4$ is 0.194 , indicating that $19.4 \%$ of the year-firms were audited by one of the Big 4 auditors.
Table 2: Descriptive Statistics $(n=3,102)$

\begin{tabular}{|c|c|c|c|c|c|}
\hline Variable & Mean & $\begin{array}{c}\text { Standard } \\
\text { Deviation }\end{array}$ & Minimum & Median & Maximum \\
\hline CRASH & 0.241 & 0.428 & 0.000 & 0.000 & 1.000 \\
\hline NSKEW & -0.130 & 0.910 & -2.777 & -0.113 & 2.486 \\
\hline$D U V O L$ & -0.062 & 0.395 & -0.996 & -0.065 & 0.957 \\
\hline$F R O$ & 0.053 & 0.057 & 0.000 & 0.033 & 0.278 \\
\hline$B I G 4$ & 0.194 & 0.395 & 0.000 & 0.000 & 1.000 \\
\hline SIZE & 9.191 & 1.633 & 6.391 & 8.911 & 13.752 \\
\hline SIGMA & 0.044 & 0.026 & 0.010 & 0.037 & 0.139 \\
\hline$R E T$ & -0.132 & 0.177 & -1.026 & -0.066 & -0.005 \\
\hline$M B$ & 1.858 & 2.602 & 0.171 & 1.008 & 18.052 \\
\hline$L E V$ & 0.485 & 0.196 & 0.087 & 0.491 & 0.885 \\
\hline$R O A$ & 0.046 & 0.084 & -0.320 & 0.040 & 0.340 \\
\hline
\end{tabular}

Variable definitions: refer to <Table $1>$.

\subsection{Correlation Analysis}

<Table 3> shows the correlation between the main variables. The variables of interest (FRO, BIG4) and the crash risk variables (CRASH, NSKEW, DUVOL) show partially insignificant results. Therefore, it is necessary to examine hypotheses using regression model including control variables in the model.

Table 3: Pearson's Correlation $(n=3,102)$

\begin{tabular}{|c|c|c|c|c|c|c|c|c|c|c|}
\hline & NSKEW & DUVOL & FRO & BIG4 & SIZE & SIGMA & $R E T$ & $M B$ & LEV & $R O A$ \\
\hline CRASH & 0.577 & 0.546 & 0.006 & -0.025 & 0.010 & -0.069 & 0.053 & -0.020 & 0.050 & -0.002 \\
\hline NSKEW & & 0.961 & -0.036 & 0.022 & 0.174 & -0.171 & 0.144 & -0.024 & 0.025 & 0.078 \\
\hline \multirow{2}{*}{ DUVOL } & & & -0.036 & 0.025 & 0.170 & -0.179 & 0.151 & -0.028 & 0.030 & 0.069 \\
\hline & & & $(0.044)$ & $(0.163)$ & $(<.001)$ & $(<.001)$ & $(<.001)$ & $(0.115)$ & $(0.099)$ & $(<.001)$ \\
\hline$F R O$ & & & & -0.189 & -0.212 & 0.303 & -0.247 & 0.256 & 0.056 & 0.048 \\
\hline BIG4 & & & & & $(<.001)$ & $(<.001)$ & $(<.001)$ & $(<.001)$ & $(<.001)$ & $(<.001)$ \\
\hline \multirow{2}{*}{ SIZE } & & & & & & -0.262 & 0.240 & 0.037 & -0.061 & 0.150 \\
\hline & & & & & & $(<.001)$ & $(<.001)$ & $(0.042)$ & $(<.001)$ & $(<.001)$ \\
\hline \multirow{2}{*}{ SIGMA } & & & & & & & -0.953 & 0.367 & -0.017 & 0.039 \\
\hline & & & & & & & $(<.001)$ & $(<.001)$ & $(0.3461)$ & $(0.029)$ \\
\hline RET & & & & & & & & -0.346 & 0.023 & -0.007 \\
\hline LEV & & & & & & & & & & $(<.001)$ \\
\hline
\end{tabular}

Variable definitions: refer to $<$ Table $1>$. Values in parentheses are $p$-values.

\subsection{Main Results}

<Table 4> shows the Hypothesis 1 verification results using the prior 3-years moving sum of the absolute value of discretionary accruals (FRO) and crash risk dummy variable
$(C R A S H)$ as a dependent variable. Financial reporting opacity variable $(F R O)$ shows a positive relationship with $C R A S H$ at the $10 \%$ significance level. This result is consistent with Hypothesis 1, which states that a firm with more opaque financial reporting increases crash risk. 
Table 4: Effect of Financial Reporting Opacity on Crash Risk Dependent Variable: Crash Risk Dummy Variable

\begin{tabular}{|c|c|c|}
\hline variables & coefficient & z-value \\
\hline Intercept & -0.825 & $5.751^{* *}$ \\
\hline$F R O$ & 1.406 & $2.7195^{*}$ \\
\hline SIZE & 0.013 & 0.2189 \\
\hline SIGMA & -21.242 & $13.5132^{\star \star *}$ \\
\hline$R E T$ & -2.232 & $7.3045^{\star \star \star}$ \\
\hline$M B$ & -0.013 & 0.4753 \\
\hline LEV & 0.750 & $9.8209^{* \star *}$ \\
\hline$R O A$ & 0.393 & 0.4687 \\
\hline Industry dummy & \multicolumn{2}{|c|}{ Included } \\
\hline Year dummy & \multicolumn{2}{|c|}{ Included } \\
\hline Likelihood Ratio & \multicolumn{2}{|c|}{$71.528^{\star \star \star}$} \\
\hline Pseudo Adjusted $\mathrm{R}^{2}$ & \multicolumn{2}{|c|}{0.02} \\
\hline $\mathrm{N}$ & \multicolumn{2}{|c|}{3,102} \\
\hline
\end{tabular}

${ }^{\star \star *},{ }^{* *}$, and ${ }^{*}$ denote statistical significance at the $0.01,0.05$, and 0.10 levels, respectively.

Variable definitions: refer to $<$ Table $1>$.

$<$ Table 5> shows the Hypothesis 2 verification results using the Big 4 accounting firms. As in 〈Table 5>, BIG4 shows a negative relationship with $C R A S H$ at the $5 \%$ significance level. This result is consistent with Hypothesis 2 , which states that firms audited by a Big 4 accounting firm (the proxy for audit quality) experience less crash risk than those who were not.

Table 5: Effect of BIG4 on Crash Risk Dependent Variable: Crash Risk Dummy Variable

\begin{tabular}{|c|c|c|}
\hline variables & coefficient & z-value \\
\hline Intercept & -0.843 & $6.001^{* *}$ \\
\hline BIG4 & -0.277 & $4.208^{\star *}$ \\
\hline SIZE & 0.019 & 0.434 \\
\hline SIGMA & -20.209 & $12.541^{\star \star \star}$ \\
\hline$R E T$ & -2.135 & $6.760^{* * *}$ \\
\hline$M B$ & -0.010 & 0.294 \\
\hline LEV & 0.777 & $10.542^{\star \star \star}$ \\
\hline$R O A$ & 0.365 & 0.396 \\
\hline Industry dummy & \multicolumn{2}{|c|}{ Included } \\
\hline Year dummy & \multicolumn{2}{|c|}{ Included } \\
\hline Likelihood Ratio & \multicolumn{2}{|c|}{$69.283^{* * *}$} \\
\hline Pseudo-Adjusted $\mathrm{R}^{2}$ & \multicolumn{2}{|c|}{0.021} \\
\hline $\mathrm{N}$ & \multicolumn{2}{|c|}{3,102} \\
\hline
\end{tabular}
${ }^{\star * *},{ }^{* *}$, and ${ }^{*}$ denote statistical significance at the $0.01,0.05$, and 0.10 levels, respectively.

Variable definitions: refer to $<$ Table 1>

$<$ Table 6> shows the Hypothesis 1 verification results using negative conditional return skewness (NSKEW) as a dependent variable. Financial reporting opacity variable (FRO) shows a positive relationship with $C R A S H$ at the 5\% significance level implying that a firm with more opaque financial reporting increases crash risk.
Table 6: Effect of Financial Reporting Opacity on Negative Conditional Return Skewness

\begin{tabular}{|c|c|c|}
\hline \multicolumn{3}{|c|}{ Dependent Variable: Negative conditional return skewnes } \\
\hline variables & coefficient & t-value \\
\hline Intercept & -0.520 & $-4.03^{\star * *}$ \\
\hline FRO & 0.636 & $2.01^{* *}$ \\
\hline SIZE & 0.081 & $7.4^{\star \star *}$ \\
\hline SIGMA & -11.780 & $-5.5^{\star * *}$ \\
\hline$R E T$ & -1.097 & $-3.62^{\star \star \star}$ \\
\hline$M B$ & -0.008 & -1.19 \\
\hline LEV & 0.250 & $2.87^{\star \star \star}$ \\
\hline$R O A$ & 0.875 & $4.32^{* * *}$ \\
\hline Industry dummy & \multicolumn{2}{|c|}{ Included } \\
\hline Year dummy & \multicolumn{2}{|c|}{ Included } \\
\hline F-value & \multicolumn{2}{|c|}{$13.91^{\star \star \star}$} \\
\hline Adjusted $\mathrm{R}^{2}$ & \multicolumn{2}{|c|}{0.08} \\
\hline $\mathrm{N}$ & \multicolumn{2}{|c|}{3,102} \\
\hline
\end{tabular}

As in $\langle$ Table 7〉, BIG4 shows a negative relationship with on negative conditional return skewness (NSKEW) at the $10 \%$ significance level. This result support Hypothesis 2 as well.

Table 7: Effect of BIG4 on Negative Conditional Return Skewness Dependent Variable: Negative conditional return skewness

\begin{tabular}{|c|c|c|}
\hline variables & coefficient & t-value \\
\hline Intercept & -0.515 & $-3.99^{\star \star \star}$ \\
\hline BIG4 & -0.084 & $-1.69^{*}$ \\
\hline$S I Z E$ & 0.082 & $7.37^{\star \star \star}$ \\
\hline SIGMA & -11.255 & $-5.32^{\star \star \star}$ \\
\hline$R E T$ & -1.046 & $-3.47^{\star \star \star}$ \\
\hline$M B$ & -0.006 & -0.95 \\
\hline LEV & 0.259 & $2.96^{\star \star *}$ \\
\hline$R O A$ & 0.864 & $4.27^{\star \star \star}$ \\
\hline Industry dummy & \multicolumn{2}{|c|}{ Included } \\
\hline Year dummy & \multicolumn{2}{|c|}{ Included } \\
\hline F-value & \multicolumn{2}{|c|}{$13.84^{\star \star \star}$} \\
\hline Adjusted $\mathrm{R}^{2}$ & \multicolumn{2}{|c|}{0.08} \\
\hline $\mathrm{N}$ & \multicolumn{2}{|c|}{3,102} \\
\hline
\end{tabular}

${ }^{* \star *},{ }^{* *}$, and ${ }^{*}$ denote statistical significance at the $0.01,0.05$, and 0.10 levels, respectively.

Variable definitions: refer to $<$ Table $1>$.

$<$ Table 8> shows the Hypothesis 1 verification results using $3^{\text {rd }}$ measure of crash risk down-to-up volatility $(D U V O L)$ as a dependent variable. Financial reporting opacity variable $(F R O)$ shows a positive relationship with CRASH at the 5\% significance level stating that a firm with more opaque financial reporting increases crash risk. 
Table 8: Effect of Financial Reporting Opacity on Down-to-Up Volatility

\begin{tabular}{|c|c|c|}
\hline \multicolumn{3}{|c|}{ Dependent Variable: Down-to-Up Volatility } \\
\hline variables & coefficient & t-value \\
\hline Intercept & -0.214 & $-3.85^{\star \star \star}$ \\
\hline FRO & 0.303 & $2.22^{\star *}$ \\
\hline SIZE & 0.034 & $7.2^{\star \star \star}$ \\
\hline SIGMA & -5.272 & $-5.7^{* \star *}$ \\
\hline RET & -0.486 & $-3.72^{\star \star \star}$ \\
\hline$M B$ & -0.003 & -1.15 \\
\hline LEV & 0.109 & $2.9^{\star \star \star}$ \\
\hline$R O A$ & 0.349 & $3.99^{* * *}$ \\
\hline Industry dummy & \multicolumn{2}{|c|}{ Included } \\
\hline Year dummy & \multicolumn{2}{|c|}{ Included } \\
\hline F-value & \multicolumn{2}{|c|}{$15.55^{\star \star \star}$} \\
\hline Adjusted $\mathrm{R}^{2}$ & \multicolumn{2}{|c|}{0.089} \\
\hline $\mathrm{N}$ & \multicolumn{2}{|c|}{3,102} \\
\hline
\end{tabular}

As in <Table 9>, BIG4 shows a negative relationship with on $3^{\text {rd }}$ measure of crash risk down-to-up volatility $(D U V O L)$ at the $1 \%$ significance level. This result is consistent with Hypothesis 2.

Table 9: Effect of BIG4 on Negative Conditional Return Skewness Dependent Variable: Negative conditional return skewness

\begin{tabular}{|c|c|c|}
\hline variables & coefficient & t-value \\
\hline Intercept & -0.211 & $-3.78^{* \star \star}$ \\
\hline BIG4 & -0.037 & $-1.74^{*}$ \\
\hline SIZE & 0.034 & $7.16^{\star * \star}$ \\
\hline SIGMA & -5.017 & $-5.48^{* * \star}$ \\
\hline$R E T$ & -0.462 & $-3.55^{\star \star \star}$ \\
\hline$M B$ & -0.002 & -0.88 \\
\hline LEV & 0.113 & $2.99^{* \star \star}$ \\
\hline$R O A$ & 0.344 & $3.93^{\star * \star}$ \\
\hline Industry dummy & \multicolumn{2}{|c|}{ Included } \\
\hline Year dummy & \multicolumn{2}{|c|}{ Included } \\
\hline F-value & \multicolumn{2}{|c|}{$15.45^{\star \star \star}$} \\
\hline Adjusted $\mathrm{R}^{2}$ & \multicolumn{2}{|c|}{0.089} \\
\hline $\mathrm{N}$ & \multicolumn{2}{|c|}{3,102} \\
\hline
\end{tabular}

${ }^{* * *},{ }^{* *}$, and ${ }^{*}$ denote statistical significance at the $0.01,0.05$, and 0.10 levels, respectively.

Variable definitions: refer to $<$ Table $1>$.

\section{Conclusion}

This study finds that the financial report opacity measured by the company's earnings management behavior had a positive effect on future crash risk. In addition, we found that firms with high audit quality measured by Big4 accounting firms experienced less crash risk. These results were all robust in the three measures of crash risk.

Investors are generally more sensitive to declines in stock price than rises; their response is even more significant when the negative information accumulated by management reaches a critical point and is spread to the market all at once (Kothari et al., 2009). Therefore, this study provides implications for financial reporting and audit quality to external stakeholders who wants to avoid losses. Furthermore, the results of this study have significant implications for the board of directors, who have the right to appoint auditors. Specifically, firms who have difficulty attracting investors due to stock price crashes can increase firm value by appointing highly skilled auditors.

This study has a contribution to that the first research to verify the relationship between financial reporting opacity, audit quality, and crash risk using Japanese listed companies. In addition, this paper measures crash risk in three ways to increase the robustness of the study results. Future research is expected to expand the results of this paper by adding variables related to corporate governance of Japanese listed companies.

\section{References}

Aman, H. (2013). An analysis of the impact of media coverage on stock price crashes and jumps: Evidence from Japan. Pacific-Basin Finance Journal, 24, 22-38.

An, H., \& Zhang, T. (2013). Stock price synchronicity, crash risk, and institutional investors. Journal of Corporate Finance, 21, 1-15.

Becker, C. L., Defond, M. L., Mark, L., Jiambalvo, J., \& Sunramanyam, K. R. (1998). The effect of audit quality on earnings management. Contemporary Accounting Research, 15(Spring), 1-24.

Callen, J. L., \& Fang, X. (2013). Institutional investor stability and crash risk: monitoring versus short-termism? Journal of Banking and Finance, 37, 3047-3063.

Callen, J. L., \& Fang, X. (2015). Short interest and crash risk. Journal of Banking and Finance, 60, 181-194.

Callen, J. L., \& Fang, X. (2017). Crash risk and the auditorclient relationship. Contemporary Accounting Research, 34(3), 1715-1750.

Chen, J., Hong, H., \& Stein, J. (2001). Forecasting crashes: Trading volume, past returns, and conditional skewness in stock prices. Journal of Financial Economics, 61, 345-381.

Chen, C., Kim, J. B., \& Yao, L. (2017). Earnings smoothing: Does it exacerbate or constrain crash risk? Journal of Corporate Finance, 42, 36-54.

DeAngelo, L. E. (1981). Auditor size and audit quality. Journal of Accounting and Economics, 3(December), 183-199.

Ertugrul, M., Lei, J., Qiu, J., \& Wan, C. (2017). Annual report readability, tone ambiguity, and the cost of borrowing. Journal of Financial and Quantitative Analysis, 52(2), 811-836.

Francis, J. R., Maydew, E. L., \& Sparks, H. C. (1999). The role of big 6 auditors in the credible reporting of accruals. Auditing: A Journal of Practice and Theory, 18, 17-35.

Healy, P. M., \& Palepu, K. G. (2001). Information asymmetry, corporate disclosure, and the capital markets: A review of the empirical disclosure literature. Journal of Accounting and Economics, 31, 405-440. 
Huang, W., Liu, Q., Rhee, G., \& Wu, F. (2012). Extreme downside risk and expected stock returns. Journal of Banking and Finance, 36(5), 1492-1502.

Hutton, A. P., Marcus, A. J., \& Tehranian, H. (2009). Opaque financial reports, R2 and crash risk. Journal of Financial Economics, 94, 67-86.

Ibragimov, R., \& Walden, J. (2007). The limits of diversification when losses may be large. Journal of Banking and Finance, 31(8), 2551-2569.

Jensen, M. C., \& Meckling, W. H. (1976). Theory of the firm: Managerial behavior, agency costs and ownership structure. Journal of Financial Economics, 3, 305-360.

Jin, L., \& Myers, S. C. (2006). R ${ }^{2}$ around the world: New theory and new tests. Journal of financial Economics, 79(2), 257-292.

Kim, J. B., Li, Y., \& Zhang, L. (2011). Corporate tax avoidance and crash risk: Firm-level analysis. Journal of Financial Economics, 100, 639-662.

Kim, Y., Li, H., \& Li, S. (2014). Corporate social responsibility and crash risk. Journal of Banking and Finance, 43, 1-13.

Kim, J. B., \& Zhang, L. (2015) Accounting conservatism and crash risk: Firm-level evidence. Contemporary Accounting Research, 33, 412-441.

Kim, J. B., Wang, Z., \& Zhang, L. (2016). CEO overconfidence and stock price crash risk. Contemporary Accounting Research, 33, 1720-1749.

Kothari, S. P., Leone, A. J., \& Wasley, C. E. (2005). Performance matched discretionary accrual measures. Journal of Accounting and Economics, 39(1), 163-197.

Kothari, S. P., Shu, S., \& Wysocki, P. D. (2009). Do manager withhold bad news? Journal of Accounting Research, 47, 241-276.

Krishnan, G. (2003). Does Big 6 auditor industry expertise constrain earnings management? Accounting Horizons, 17(supplement), 1-16.

Morck, R., Yeung, B., \& Yu, W. (2000). The information content of stock markets: Why do emerging markets have synchronous stock price movement? Journal of Financial Economics, 58, 215-260.

Myers, J., Myers, L., \& Omer, T. (2003). Exploring the term of the auditor-client relationship and the quality of earnings: A case for mandatory auditor rotation? The Accounting Review, 78(3), 779-799.

Palmrose, Z. V. (1989). The relation of audit contract type to audit fees and hours. The Accounting Review, 64, 488500.

Robin, A., \& Zhang, H. (2015). Do industry-specialist auditors influence stock price crash risk? Auditing: A Journal of Practice and Theory, 34, 47-79. 